\title{
Reversible and Competitive Inhibition of Enteropeptidase by 1-trans-Epoxysuccinyl-L-leucylamido(4-guanidino)butane (E-64)
}

\author{
Masashi Matsushima ${ }^{1,2,5}$, Naohisa Yahagi $^{1}$, Masao Ichinose ${ }^{1,6}$, Kazumasa Miki ${ }^{1,7}$, Masao Omata ${ }^{1}$, \\ Tsunehiko Higuchi ${ }^{3}$, Hideshi INOuE ${ }^{2,4}$, Takayuki TaKahashi ${ }^{2,8}$ and Kenji TaKahashi ${ }^{2,4}$ \\ ${ }^{1}$ Department of Gastroenterology, Faculty of Medicine, ${ }^{2}$ Department of Biophysics and Biochemistry, Graduate School of Science \\ and ${ }^{3}$ Graduate School of Pharmaceutical Sciences, The University of Tokyo, Bunkyo-ku, Tokyo 113-0033 \\ and ${ }^{4}$ Department of Molecular Biochemistry, School of Life Science, Tokyo University of Pharmacy and Life Science, 1432-1 \\ Horinouchi, Hachioji, Tokyo 192-0392, Japan
}

(Received 12 October 2001; and accepted 18 October 2001)

\begin{abstract}
1-trans-Epoxysuccinyl-L-leucylamido(4-guanidino)butane (E-64), an well known cysteine proteinase inhibitor, which specifically inhibits cysteine proteinases by irreversibly modifying the free sulfhydryl group of the active site cysteine residue with its epoxide group, was shown to strongly inhibit the serine proteinase enteropeptidase, the key enzyme in the intestinal protein digestion cascade, in a reversible and competitive manner with a $K_{\mathrm{i}}$ value of $12 \mu \mathrm{M}$. The derivative of E-64, in which the epoxide group was reacted with 2-mercaptoethanol, also inhibited the enzyme, whereas 1-trans-epoxysuccinyl-L-leucylamido-3-methylbutane (E-64c), which lacks the guanidinium group, had no inhibitory effect on the enzyme, indicating that the guanidinium group is essential for the inhibition of enteropeptidase.
\end{abstract}

h 1-trans-Epoxysuccinyl-L-1eucylamido(4guanidino)butane (E-64) has long been known as one of the active-site-directed irreversible inhibitors of cysteine proteinases. It specifically

This study was supported in part by grants-in-aid for scientific research from the Ministry of Education, Science, Sports and Culture of Japan.

Correspondence to: Dr Kenji Takahashi at the above address. ${ }^{4}$

Tel: +81-426-76-7146; Fax: +81-426-76-7149; Email: kenjitak@1s.toyaku.ac.jp

${ }^{5}$ Present address: Department of Internal Medicine, Tokai University School of Medicine, Kanagawa 259-1193. ${ }^{6}$ Second Department of Internal Medicine, Wakayama Medical University, Wakayama 6410012. ${ }^{7}$ First Department of Internal Medicine, Toho University School of Medicine, Tokyo 1438541. ${ }^{8}$ Graduate School of Science, Hokkaido University, Sapporo 060-0810.

Abbreviations:E-64, 1-trans-epoxysuccinyl-Lleucylamido(4-guanidino)butane; E-64c, 1-transepoxysuccinyl-L-leucylamido-3-methylbutane. inhibits cysteine proteinases irreversibly and noncompetitively by reaction of its reactive epoxide group with the thiol group of a cysteine residue at the active site of the enzymes $(2,3,5,6)$. However, we recently found that the serine proteinase enteropeptidase (EC 3.4.11.9), a specific proteinase responsible for the initial conversion of trypsinogen to trypsin in the duodenum $(7,8)$, was also inhibited strongly by this cysteine proteinase inhibitor (10). In the present study, to clarify the mechanism of this inhibition, kinetic studies were performed, and two related compounds were tested for inhibitory action against enteropeptidase. The results showed that E-64 inhibits enteropeptidase as a reversible and competitive inhibitor, different from the inhibition of cysteine proteinases, and that the presence of a guanidinium group, but not of an epoxide group, is essential for the inhibition of enteropeptidase, reflecting its $\mathrm{P} 1$ site preference for a basic residue. Indeed, trypsin, a typical serine proteinase, has also been reported to be inhibited by E-64 in a 
similar manner (11).

Gly-Asp-Asp-Asp-Asp-Lys- $\beta$-naphthylamide and 1-trans-epoxysuccinyl-L-leucylamido(4guanidino)butane (E-64) (Fig. 1) were purchased from Sigma and Peptide Institute Inc. (Osaka, Japan), respectively. 1-trans-Epoxysuccinyl-Lleucylamido-3-methylbutane (E-64c) (Fig. 1) was kindly supplied by Taisho Pharmaceutical Co. Ltd. Iodoacetic acid (IAA) and 2mercaptoethanol were from Wako Pure Chemical Industries, Japan. Enteropeptidase was purified to homogeneity from porcine duodenal mucosa according to the procedure described in the previous paper (10). The purified enzyme preparation showed a specific activity of $12.8 \mu \mathrm{mol} / \mathrm{min} / \mathrm{mg}$ protein using the standard assay system. The enzymatic activity was assayed with Gly-AspAsp-Asp-Asp-Lys- $\beta$-naphthylamide as a substrate as described (10). In brief, $125 \mu \mathrm{L}$ of $0.1 \mathrm{M}$ Tris-HCl buffer, $\mathrm{pH} 8.0$, containing $2 \mathrm{mM}$ substrate was mixed with $10 \mu \mathrm{L}$ of an enzyme solution, and the mixture was incubated at $37^{\circ} \mathrm{C}$. The reaction was terminated by the addition of 375 $\mu \mathrm{L}$ of a coupling reagent prepared according to Barrett (1) and the absorbance at $520 \mathrm{~nm}$ was measured in a spectrophotometer. Protein concentrations were estimated colorimetrically with a Protein Assay Kit (Bio-Rad) using mouse im-

(a)

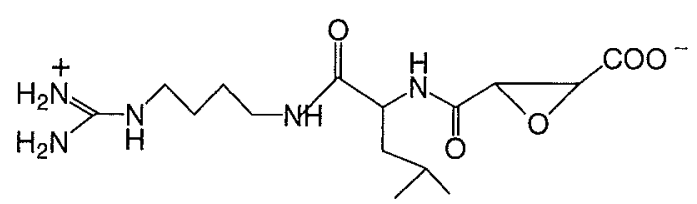

(b)

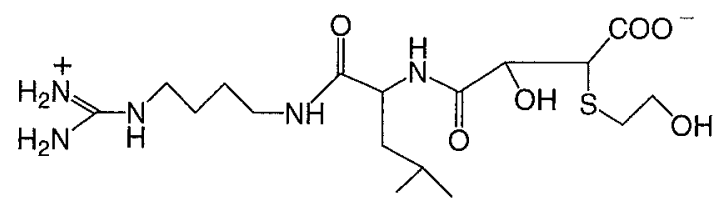

(c)

(d)
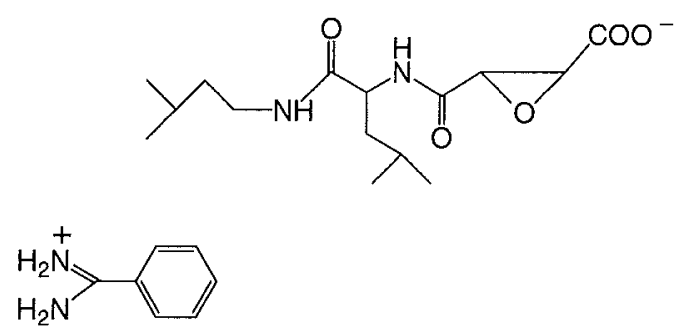

Fig. 1 Chemical structures of E-64 and related compounds. (a) E-64, (b) E-64 - 2-mercaptoethanol adduct (an assumed structure), (c) E-64c, (d) benzamidine. munoglobulin $\mathrm{G}$ as a standard protein (4). To react E-64 with 2-mercaptoethanol, E-64 $(4.8 \mathrm{mg})$ was incubated with $373 \mathrm{mM}$ 2-mercaptoethanol in $400 \mu \mathrm{L}$ of $100 \mathrm{mM}$ Tris- $\mathrm{HCl}, \mathrm{pH} 8.0$, at $50^{\circ} \mathrm{C}$ for 3 days under nitrogen. The reaction mixture was further incubated with $1.0 \mathrm{~mL}$ of $0.4 \mathrm{M}$ iodoacetic acid in $0.1 \mathrm{M}$ Tris- $\mathrm{HCl}, \mathrm{pH} 8.0$, at room temperature for $1 \mathrm{~h}$ in the dark to alkylate any 2-mercaptoethanol remaining. After acidification with $20 \mu \mathrm{L}$ of $6 \mathrm{~N} \mathrm{HCl}$, the sample was injected to a $\mathrm{C} 18$ reverse phase HPLC column equilibrated with $0.2 \%$ trifluoroacetic acid and was eluted with a linear concentration gradient of acetonitrile. The major reaction product was collected and confirmed by NMR to be the Sadduct of 2-mercaptoethanol to the epoxide group of E-64 (Fig. 1). It was evaporated in vacuo, redissolved in water and used for the enzyme inhibition assay.

E-64 inhibited the enteropeptidase activity as shown in Fig. 2. The inhibition was competitive as shown by the double-reciplocal plot in Fig. 3a., and the $K_{\mathrm{i}}$ value was determined to be 11 $\mu \mathrm{M}$. The Dixon plot (Fig. 3b) also gave a similar $K_{i}$ value of $13 \mu \mathrm{M}$. Therefore, the average $K_{i}$ value was $12 \pm 1 \mu \mathrm{M}$. This is in contrast with the irreversible inhibition of cysteine proteinases by E-64 $(2,3,5,6)$. The inhibition took place almost instantly upon mixing of the enzyme and the inhibitor, and the inhibition did not proceed any further. Practically the same extent of inhibition was obtained with the E-64 derivative in which the epoxide group had been modified with 2-

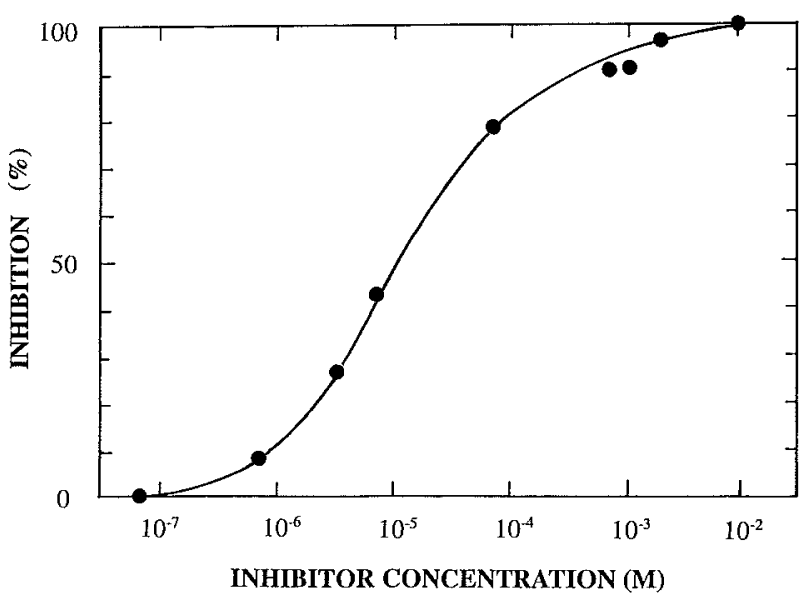

Fig. 2 Inhibition of enteropeptidase by various concentrations of E-64. The assay was performed under the standard conditions except that various concentrations of E-64 were used. 
(a)
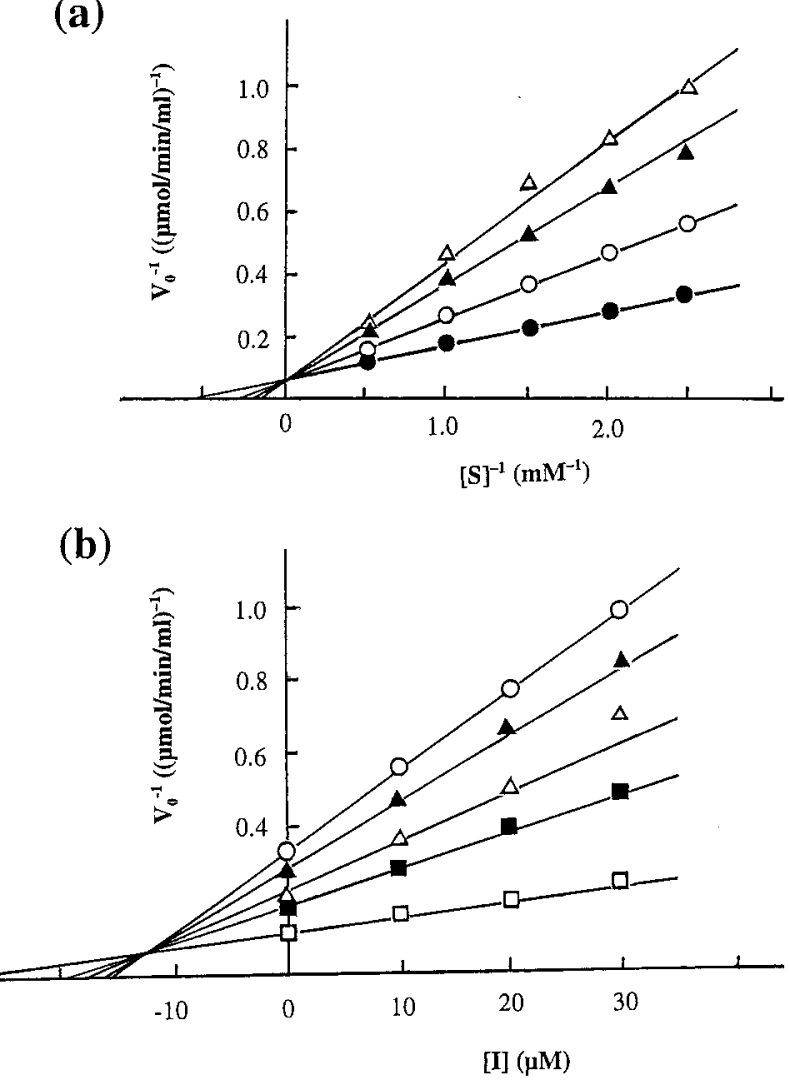

Fig. 3 Kinetic analysis of inhibition of enteropeptidase activity by E-64. The assay was performed under the standard conditions except that various concentrations of substrate and E-64 were used. $v_{0}$, Initial velocity $(\mu \mathrm{mol} / \mathrm{min} / \mathrm{mL})$; [S], substrate concentration (mM); $[\mathrm{I}]$, inhibitor concentration $(\mu \mathrm{M})$. (a) Double reciprocal plot. $\left(\mathrm{v}_{0}{ }^{-1}\right.$ versus $\left.[\mathrm{S}]^{-1}\right)$. E-64 concentrations were $0(\bullet), 10(\bigcirc), 20(\Delta)$ and $30(\triangle)$ $\mu \mathrm{M}$. (b) Dixon plot $\left(\mathrm{V}_{0}^{-1}\right.$ versus $\left.[\mathrm{I}]\right)$. The substrate concentrations were $0.4(\bigcirc), 0.5(\mathbf{\Delta}), 0.67(\triangle), 1.0$ $(\boldsymbol{\square})$ and $2.0(\square) \mathrm{mM}$.

mercaptoethanol. This result clcarly shows that the epoxide group is not important for the inhibition of enteropeptidase. On the other hand, the enzyme was unsusceptible to E-64c, another derivative of E-64, which is also known as a cysteine proteinase inhibitor (4), having an epoxide group, but no guanidinium group. The extent of inhibition by $1 \mathrm{mM}$ E-64c was less than $5 \%$; at this concentration of E-64, the enzyme was nearly completely inhibited. Therefore, the positively charged guanidinium group was indicated to be essential for enteropeptidase inhibition. This is consistent with the fact that benzamidine was also inhibitory to the enzyme; the extents of inhibition were approximately $85 \%$ and $70 \%$ with $0.1 \mathrm{mM}$ E-64 and $0.1 \mathrm{mM}$ benzamidine, respectively, under the standard assay conditions. These results are fairly similar to those obtained for trypsin; $K_{\text {i }}$ values of $30 \mu \mathrm{M}$ and $20 \mu \mathrm{M}$ were reported for the inhibition of bovine trypsin by E-64 and benzamidine, respectively (11), and demonstrate the primary importance of the positively charged group for the inhibition of enterokinase. This is reasonable since the enzyme is one of the trypsintype serine proteinases that require a positively charged residue (i.e.,arginine or lysine) at the P1 position of the substrates. The guanidinium group of E-64 is thought to interact with the $\beta$-carboxylate group of Asp 181 in the S1 pocket of the enzyme (9) with the epoxide group far apart from it. Although E-64 was shown, in this study, to be a strong inhibitor for the serine proteinase enteropeptidase, it should be kept in mind that it is potentially capable of inhibiting not only cysteine proteinases but any class of proteinases with trypsin-like specificity.

\section{Acknowledgement}

We are grateful to Taisho Pharmaceutical Co., Ltd. for the generous supply of E64c.

\section{REFERENCES}

1. Barrett, A.J. (1977) Cathepsin B and other thiol proteinases. in Proteinases in Mammalian Cells and Tissues (Barrett, A.J., ed.) pp. 181-208, North-Holland Publishing, Amsterdam.

2. Barrett, A.J., Kembhavi, A.A. and Hanada, K. (1981) E-64 [L-trans-epoxysucccinyl-leucyl-amido(4-guanidino) butane] and related epoxides as inhibitors of cysteine proteinases. Acta Biol. Med. Ger. 40, 1513-1517.

3. Barrett, A.J., Kembhavi, A.A., Brown, M.A., Kirschke, H., Knight, C.G., Tamai, M. and Hanada, K. (1982) L-transEpoxysucccinyl-leucylamido(4-guanidino)butane] (E-64) and its analogues as inhibitors of cysteine proteinases including cathepsins B, H and L. Biochem. J., 201, 189198.

4. Bradford, M.M. (1976) A rapid and sensitive method for the quantitation of microgram quantities of protein utilizing the principle of protein-dye binding. Anal. Biochem., 72, 248-254.

5. Hanada, K., Tamai, M., Yamagishi, M., Ohmura, S., Sawada, J. and Tanaka, I. (1978) Isolation and characterization of E-64, a new thiol protease inhibitor. Agric. Biol. Chem., 42, 523-528.

6. Hashida, S., Towatari, T., Kominami, E. and Katunuma N. (1980) Inhibitions by E-64 derivatives of rat liver cathepsin $\mathrm{B}$ and cathepsin $\mathrm{L}$ in vitro and in vivo. $J$. Biochem., 88, 1805-1811.

7. Light, A. and Junska, H. (1989) Enterokinase (enteropeptidase): comparative aspects. Trends Biochem. Sci. 14, 
$110-112$.

8. Lu, D. and Sadler, J. E. (1998) Enteropeptidase in Handbook of Proteolytic Enzymes (Barrett, A. J., Rawlings, N. D. and Woessner, J. F., eds.) pp. 50-54 Academic Press, San Diego.

9. Matsushima, M., Ichinose, M., Yahagi, N., Kakei, N., Tsukada, S., Miki, K., Kurokawa, K., Tashiro, K., Shiokawa, K., Shinomiya, K., Umeyama, H., Inoue, H., Takahashi, T. and Takahashi, K. (1994) Structural characterization of porcine enteropeptidase. J. Biol. Chem., 269, 19976-19982.

10. Matsushima, M., Ichinose, M., Yahagi, N., Tsukada-Kato, S., Miki, K., Omata, M., Kim, Y-T., Ito, H., Takahashi, T,,
Sakurai, Y., Tsuchiya, Y., Athauda, S.B.P., Inoue, H. and Takahashi, K. (1999) Purification and further characterization of enteropeptidase from porcine duodenum. $J$. Biochem., 125, 947-951.

11. Sreedharan, S.K., Verma, C., Caves, L.S.D., Brocklehurst, S.M., Gharbia, S.E., Shah, H.N. and Brocklehurst, K. (1996) Demonstration that 1-trans-epoxysuccinyl-Lleucylamido-(4-guanidino)butane (E-64) is one of the most effective low $\mathrm{Mr}$ inhibitors of trypsin-catalysed hydrolysis. Characterization by kinetic analysis and energy minimization and molecular dynamics simulation of the E-64- $\beta$-trypsin complex. Biochem. J. 316, 777-786. 